\title{
The Impact of Flour from White Bean (Phaseolus vulgaris) on Rheological, Qualitative and Nutritional Properties of the Bread
}

\author{
Ibrahim Hoxha1, Gafur Xhabiri2 ${ }^{*}$, Ramadan Deliu ${ }^{3}$ \\ ${ }^{1}$ Faculty of Agribusiness, University of "Haxhi Zeka”, Peja, Kosovo \\ ${ }^{2}$ Faculty of Food Technology and Nutrition, University of Tetova, Tetova, North Macedonia \\ ${ }^{3}$ Food Industry, M \& Sillosi, Xerxe/Rahovec, Kosovo \\ Email: ^gafur.xhabiri@unite.edu.mk
}

How to cite this paper: Hoxha, I., Xhabiri, G. and Deliu, R. (2020) The Impact of Flour from White Bean (Phaseolus vulgaris) on Rheological, Qualitative and Nutritional Properties of the Bread. Open Access Library Journal, 7: e6059.

https://doi.org/10.4236/oalib.1106059

Received: January 8, 2020

Accepted: February 1, 2020

Published: February 4, 2020

Copyright $\odot 2020$ by author(s) and Open Access Library Inc.

This work is licensed under the Creative Commons Attribution International License (CC BY 4.0).

http://creativecommons.org/licenses/by/4.0/

\begin{abstract}
The white bean represents the most important nutrition legume in many countries in the world, including Kosovo. It has high protein, dietary fibers and mineral content and it is mainly used in the form of cooked food. This paper has the objective to review the parameters of rheological properties, qualitative properties and nutrition values of the bread produced by adding various percentages of the flour obtained from white bean. The results from rheological analysis of the dough indicate that with the increase of bean flour content the water absorption and the dough development time are increased; however there is a considerable tendency to reduce the extensibility, the resistance and dough energy. In addition, the increase of the white bean amount influences the decrease of the qualitative properties of bread. With the increase of the white bean flour content, one observes a considerable increase in nutrition values, especially that of proteins, cellulose and minerals. Whereas the positive Pearson correlation between qualitative properties and nutrition in the bread thus obtained exists only in the level $p<0.01$, however not also for $p<0.05$.
\end{abstract}

\section{Subject Areas}

Food Science \& Technology, Nutrition

\section{Keywords}

White Bean, Rheological Properties, Bread, Nutrition Values

\section{Introduction}

The bread represents one of the main and most important foods in the world; 
however in certain developed countries one observes the decreasing consumption due to the changes in nutrition habits. Therefore, the baking industry is in the continuous process of seeking diversity and alternative innovations, which would in turn satisfy the nutrition needs of the people who are conscious regarding their health [1]. The use of other types of flour in the baking technology for the production of bread with high nutrition value is in increasing trend in the last years. Therefore, the partial substitution of the wheat flour with flour obtained from the vegetables in the production of baking products and the positive effects are reported by many researchers [2] [3] [4].

There are more research papers on the use of flour obtained from vegetables in the production of bread, despite this there are only a few studies concerning the use of white bean flour. The latter is a valuable legume in Kosovo due to its high nutritious values; however it is mostly consumed in a form of cooked food. This legume is rich in complex carbohydrates, proteins, vitamins, minerals and it is poor fat content [5]. Carbohydrates form the main part of bean with average $55 \%-65 \%$ of the dry matter, with polysaccharides as the main ingredient [6] and considerable content of dietary fibers. The protein of beans is rich with lysine and poor in terms of amino acid content that contain sulfur, whereas the proteins from cereals lack lysine and have sufficient content of sulfur amino-acids. Therefore, the combination of wheat flour with bean flour in high percentage will ensure a more favorable equilibrium between essential amino-acids by helping to overcome the malnutrition problem [7].

The beans represent an important source of minerals such as iron, phosphorus, magnesium, manganese and vitamins $\mathrm{A}, \mathrm{C}, \mathrm{E}, \mathrm{K}$ and $\mathrm{PP}$, vitamin $\mathrm{B}$ and folic acid, as well as solvable and insolvable dietary fibers which exhibit health benefits [8]. In addition, the dark varieties contain polyphenols [9].

The purpose of this paper is to research the effect of increasing the white bean flour in the various levels in the rheology properties of the dough, the qualitative properties of produced bread, the nutritious values of the bread produced and possible correlation between qualitative properties of the bread and nutritious value of the bread.

\section{Materials and Methods}

\subsection{Materials}

For production of bread one used the flour of type 500 Finessa produced by company M \& Sillosi, Xerxe-Rahovec, this type of flour is ideal for production of bread in the following content: $12.4 \%$ humidity, ash 0.532 , acidity $1.9 \%$, protein $10.5 \%$ and moist gluten $25.9 \%$.

\subsection{Preparation of Bean Flour}

In this study one used the locally produced bean known as white beans of Kosovo with the following contents: humidity $10.92 \%$, protein $23.85 \%$, fat $2.0 \%$, minerals $3.2 \%$, cellulose $4.6 \%$, carbohydrates $5.2 \%$. The beans before use are hy- 
drated in a dish with water kept in room temperature for 8 hours, then after it is milled and screened in lab mill-YM1 wet wheat grinding machine-Yuceba, Izmir, Turkey in order to obtain flour.

For rheological analysis and the bread production one created a mixture with bean flour as indicated in Table 1 .

\subsection{Bread Making}

In bread production one used water according to the absorbing attributes in farinograph, salt in the amount of $1.5 \%$ and yeast-brand Digo $1.5 \%$. The mixture of bread is done using the spiral mixer with two speeds, model S M, Yucebas, Izmir, Turkey for approximately 8 minutes. The fermentation is performed in fermenters of type ALS-Zita, Belgrade, Serbia in temperature of $30^{\circ} \mathrm{C}$, for a duration of 90 minutes, whereas the baking is performed in lab oven ALS-Zita, Belgrade, Serbia in temperature of $220^{\circ} \mathrm{C}$ and for a duration of approximately 25 minutes.

\subsection{Methods of Analysis}

Physical and chemical analysis such as the content of humidity is performed in accordance with ISO 712:2009, the content of ash is performed in accordance with ISO 2171:2007, the protein content with Kjeldahl method whereby for the cereals we assume (Nx 5.7) and for the beans (NX6.25) in accordance with ISO 20483:2006, the moist gluten content is in compliance with ISO 21415-1:2006, the fat content in accordance with ISO 6492:1999, the dietary fiber content such is cellulose in accordance with ISO 6865:2000. Total carbohydrate content of the sample was determined as total carbohydrate by difference, that is by subtracting the measured protein, fat, ash and moisture from 100. The determination of rheology attributes of the dough with Brabender equipment is performed using farinograph in accordance with ISO 5530-1:2003, as well as with extensograph which is performed in accordance with ISO 5530-2:2012. Qualitative properties of the bread such are bread volume, specific volume of bread and the weight of bread are all determined based on ICC method [10].

\subsection{Statistical Analysis}

Data analysis was performed using SPSS 16 (SPSS Inc., Chicago, IL). Results were presented as mean values \pm standard deviation (SD) of three replications. Pearson's correlation was used to determine the relationship between the parameters of qualitative properties of bread and nutritive value of bread.

\section{Results and Discussion}

\subsection{Rheology Properties of the Dough Produced Using Bean Flour}

From Table 2 we can observe the rheology properties with farinograph, which indicate that the water absorption ability of the dough does not differ significantly with the increase of the percentage of bean flour, a higher percentage is 
Table 1. The bean flour content in the mixtures for rheological properties and bread production.

\begin{tabular}{ccc}
\hline Mixtures & Flour T-500 (\%) & Bean flour (\%) \\
\hline M0 & 100 & - \\
M1 & 95 & 5 \\
M2 & 90 & 10 \\
M3 & 88 & 12 \\
M4 & 85 & 15 \\
M5 & 82 & 18 \\
M6 & 80 & 20 \\
M7 & 75 & 25 \\
\hline
\end{tabular}

Table 2. The rheological properties of dough produced using bean flour.

\begin{tabular}{ccccccccc}
\hline & \multicolumn{4}{c}{ Farinograph } & \multicolumn{4}{c}{ Extensograph } \\
\cline { 2 - 8 } Mixtures & $\begin{array}{c}\text { Water } \\
\text { absorption (\%) }\end{array}$ & $\begin{array}{c}\text { Dough development } \\
\text { time (min) }\end{array}$ & $\begin{array}{c}\text { Dough Stability } \\
(\mathrm{min})\end{array}$ & $\begin{array}{c}\text { Degree of } \\
\text { softening (FU) }\end{array}$ & $\begin{array}{c}\text { Extensibility } \\
(\mathrm{mm})\end{array}$ & $\begin{array}{c}\text { Resistance } \\
(\mathrm{E} . \mathrm{U})\end{array}$ & $\begin{array}{c}\text { Energy } \\
\left(\mathrm{cm}^{2}\right)\end{array}$ & $\begin{array}{c}\text { Relation } \\
\text { R/E }\end{array}$ \\
\hline M0 & $56.3 \pm 2.04$ & $1.6 \pm 0.15$ & $0.7 \pm 0.08$ & $85 \pm 1.5$ & $141 \pm 2.02$ & $306 \pm 3.8$ & $71 \pm 1.82$ & $2.2 \pm 0.02$ \\
M1 & $56.4 \pm 1.26$ & $1.55 \pm 0.22$ & $0.25 \pm 0.02$ & $97 \pm 1.0$ & $144 \pm 2.80$ & $266 \pm 1.2$ & $64 \pm 1.08$ & $1.8 \pm 0.10$ \\
M2 & $56.1 \pm 1.22$ & $1.45 \pm 0.05$ & $0.6 \pm 0.10$ & $112 \pm 1.4$ & $122 \pm 3.42$ & $272 \pm 4.6$ & $52 \pm 2.4$ & $2.2 \pm 0.04$ \\
M3 & $56.1 \pm 3.04$ & $3.8 \pm 0.02$ & $0.75 \pm 0.18$ & $60 \pm 0.27$ & $122 \pm 2.81$ & $276 \pm 3.2$ & $52 \pm 1.2$ & $2.3 \pm 0.01$ \\
M4 & $57.2 \pm 2.64$ & $3.5 \pm 0.14$ & $1.4 \pm 0.08$ & $40 \pm 0.84$ & $119 \pm 1.50$ & $271 \pm 4.1$ & $49 \pm 3.03$ & $2.3 \pm 0.03$ \\
M5 & $57.0 \pm 1.75$ & $4.0 \pm 0.10$ & $1.4 \pm 0.08$ & $0 \pm 0.00$ & $114 \pm 2.82$ & $241 \pm 2.5$ & $42 \pm 1.4$ & $2.1 \pm 0.09$ \\
M6 & $57.6 \pm 2.58$ & $4.0 \pm 0.26$ & $0.9 \pm 0.03$ & $0 \pm 0.00$ & $115 \pm 1.54$ & $302 \pm 2.9$ & $54 \pm 1.5$ & $2.6 \pm 0.12$ \\
M7 & $57.1 \pm 2.06$ & $4.4 \pm 0.17$ & $0.8 \pm 0.02$ & $0 \pm 0.00$ & $101 \pm 1.64$ & $305 \pm 1.0$ & $48 \pm 1.4$ & $3.0 \pm 0.21$ \\
\hline
\end{tabular}

Values are means \pm standard deviations $(\mathrm{n}=3)$.

observed with the increase of $20 \%$ of bean flour or with the mixture of M6 with $57.6 \% \pm 2.58 \%$, which differs slightly with the dough prepared without the bean flour that has absorption ability of $56.3 \% \pm 2.04 \%$. The dough development time is increased gradually with the increase of the bean flour; therefore, it is higher with the mixture M7 with $4.5 \pm 0.17$ minutes. Similar effects with the dough development time are observed by [11], who have used the lentil flour and flour of white bean with 10\%, 20\% and 30\%. The increase in dough development time could be explained by interactions between the non-wheat proteins and gluten leading to a delay in the hydration and development of gluten in the presence of these ingredients [12]. Stability of dough is variable with a tendency to increase observed with mixtures M4 and M5, with $1.4 \pm 0.08$ minutes, then with the mixtures M6 and M7 there is a reduction of the stability of dough, these results are also indicated by the study of [13], who have used $15 \%, 25 \%$ and $35 \%$ of the flour from the various beans in the production of tortillas, whereby the stability of the dough in general is decreased with the increase of the percentage of the 
beans flour. The degree of softness of dough is decreased from $85 \pm 1.5 \mathrm{FU}$ for $\mathrm{M} 0$ up to $0 \pm 0.00 \mathrm{FU}$ for the mixtures M5, M6, M7.

From the rheology properties observed with extensograph, we can see that the extensibility of dough is decreased gradually with the increase of the bean flour, that is from $141 \pm 2.02 \mathrm{~mm}$ for M0 in $101 \pm 1.64 \mathrm{~mm}$ for the mixture M7, the results are similar in the study of [14] who have used the flour of beans and sorghum from $5 \%, 10 \%$ and $15 \%$ in the production of flat bread. The dough resistance up to mixture M5 is decreased then we observe an increase of the resistance of dough for M6 and M7 that reaches up to the resistance of the pure flour M0. The energy of dough is gradually decreased with the increase of the percentage of bean flour, that is from $71 \pm 1.82 \mathrm{~cm}^{2}$ for M0, up to $48 \pm 1.4 \mathrm{~cm}^{2}$ for the mixture M7. The ratio R/E with the increase of the bean flour indicates a slight tendency of increase which is mostly observed at the mixture M7, even though this ratio is within optimum limits of $1.5-2.5$ for the production of bread.

\subsection{Qualitative Properties of the Bread that Contains Bean Flour}

From Figure 1 we can see that weight of the bread increases with the increase of the bean flour, that is from $495 \mathrm{~g}$ for $\mathrm{M} 0$, or for bread without bean flour, up to $510.3 \mathrm{~g}$ for bread M7, that is with $25 \%$ of bean flour. The volume of the bread is decreased from $2176 \mathrm{~cm}^{3}$ for $\mathrm{M} 0$ down to $1764 \mathrm{~cm}^{3}$ for the mixture with highest percentage of bean flour M7. Also, the specific volume decreases with the increase of the percentage of bean flour from $10.5 \mathrm{~cm}^{3} / \mathrm{g}$ for M0 down to $8.3 \mathrm{~cm}^{3} / \mathrm{g}$ for the mixture M7. The results are similar with the study of [15] who have used flour from red bean in the ratio 5, 15 and 25\% and they have obtained the bread with lower volume and specific volume with the increase of percentage of red bean flour.

\subsection{The Nutrition Values of the Bread that Contains Bean Flour}

In Table 3 there are the nutrition values of the bread produced using bean flour. We can observe that the humidity of the produced bread is increased with the increase of the bean flour and it reached $39.2 \% \pm 1.1 \%$ for the mixture M7. The content of proteins is increased considerably with the increase of the amount of bean flour, that is from $8.7 \pm 0.05 \mathrm{~g} / 100 \mathrm{~g}$ for $\mathrm{M} 0$, up to $13.6 \pm 0.13 \mathrm{~g} / 100 \mathrm{~g}$ for the mixture M7. The fat content is also considerable increased up to $4.7 \pm 0.09$ $\mathrm{g} / 100 \mathrm{~g}$ for the mixture M7. When we talk about carbohydrates, we can clearly observe that their content in the bread produced with bean flour is significantly decreased from $56.2 \pm 1.45 \mathrm{~g} / 100 \mathrm{~g}$ for M0 to only $34.4 \pm 1.36 \mathrm{~g} / 100 \mathrm{~g}$. The cellulose which represents the dietary fibers, content in the bread produced is considerably increased that is from $1.9 \pm 0.08 \mathrm{~g} / 100 \mathrm{~g}$ for M0 up to $5.4 \pm 0.27 \mathrm{~g} / 100 \mathrm{~g}$ in the mixture M7 and [16] in their research they indicated that the best food products in the increase of total fiber consumption, of cellulose and resistant starch are the cooked peas and beans. In addition, the content of minerals in the bread produced increases with increasing amount of bean flour up to $2.8 \pm 0.13$ g/100g per M7. 


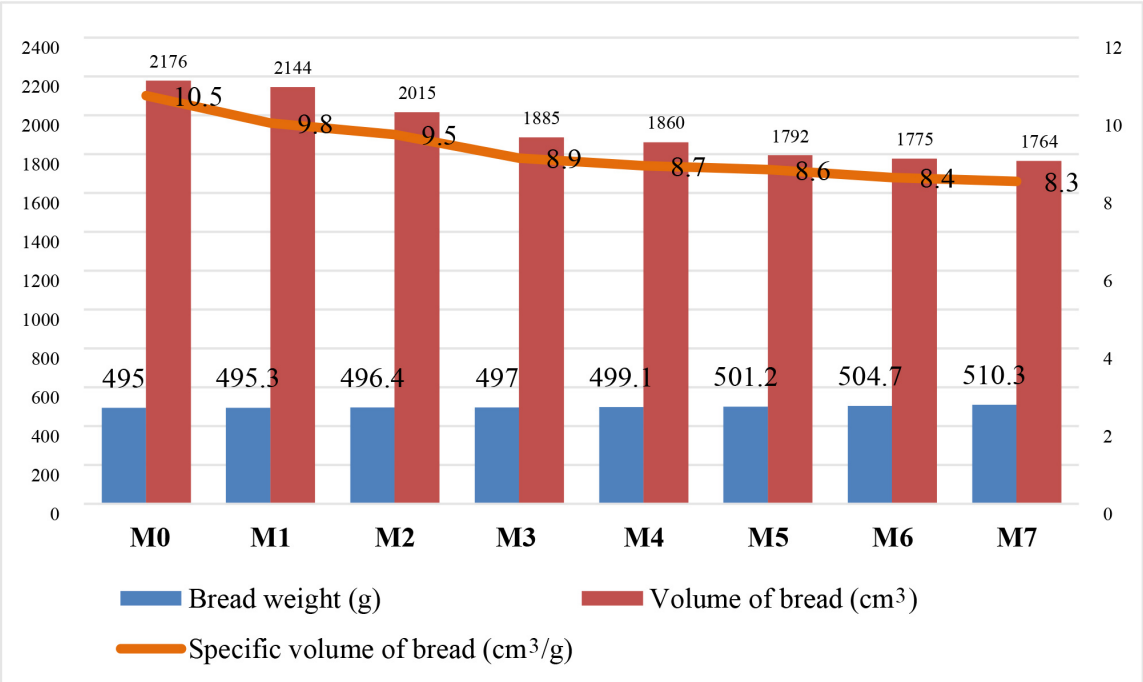

Figure 1. The qualitative properties of bread obtain from bean flour.

Table 3. Nutrition values of brad produced using bran flour.

\begin{tabular}{ccccccc}
\hline Mixtures & Moisture $(\%)$ & $\begin{array}{c}\text { Protein } \\
(\mathrm{g} / 100 \mathrm{~g})\end{array}$ & $\begin{array}{c}\text { Fats } \\
(\mathrm{g} / 100 \mathrm{~g})\end{array}$ & $\begin{array}{c}\text { Carbohydrate } \\
(\mathrm{g} / 100 \mathrm{~g})\end{array}$ & $\begin{array}{c}\text { Cellulose } \\
(\mathrm{g} / 100 \mathrm{~g})\end{array}$ & $\begin{array}{c}\text { Ash } \\
(\mathrm{g} / 100 \mathrm{~g})\end{array}$ \\
\hline M0 & $29.2 \pm 1.22$ & $8.7 \pm 0.05$ & $1.3 \pm 0.02$ & $56.2 \pm 1.45$ & $1.9 \pm 0.08$ & $1.2 \pm 0.04$ \\
M1 & $29.3 \pm 2.08$ & $8.9 \pm 0.10$ & $2.5 \pm 0.04$ & $54.3 \pm 1.37$ & $3.1 \pm 0.03$ & $1.9 \pm 0.08$ \\
M2 & $31.8 \pm 1.12$ & $9.1 \pm 0.12$ & $2.7 \pm 0.08$ & $50.8 \pm 0.59$ & $3.5 \pm 0.1$ & $2.1 \pm 0.1$ \\
M3 & $32.1 \pm 0.82$ & $9.7 \pm 0.18$ & $3.3 \pm 0.12$ & $49.2 \pm 0.88$ & $3.7 \pm 0.02$ & $2.0 \pm 0.1$ \\
M4 & $35.7 \pm 2.41$ & $10.3 \pm 0.09$ & $3.5 \pm 0.22$ & $44.2 \pm 0.94$ & $4.1 \pm 0.18$ & $2.2 \pm 0.16$ \\
M5 & $36.9 \pm 1.30$ & $12.5 \pm 0.11$ & $4.2 \pm 0.31$ & $39.5 \pm 0.53$ & $4.6 \pm 0.22$ & $2.3 \pm 0.2$ \\
M6 & $37.7 \pm 1.23$ & $12.8 \pm 0.06$ & $4.4 \pm 0.14$ & $37.3 \pm 0.51$ & $5.2 \pm 0.09$ & $2.6 \pm 0.07$ \\
M7 & $39.2 \pm 1.17$ & $13.6 \pm 0.13$ & $4.7 \pm 0.09$ & $34.4 \pm 1.36$ & $5.4 \pm 0.27$ & $2.8 \pm 0.13$ \\
\hline
\end{tabular}

Values are means \pm standard deviations $(n=3)$.

In Table 4 there is a possible Pearson correlation between the qualitative properties of the bread and nutrition values of the bread. We can observe that for the level $p<0.01$ weight of the bread there is a significant positive correlation of 0.947 with protein and high negative correlation of -0.935 with the carbohydrates; the volume of the bread has a high positive correlation of 0.942 with the carbohydrates and high negative of -0.956 with the lipids; in addition, the specific volume of the bread has a significant positive correlation of 0.925 with the carbohydrates and high negative correlation for the lipids of -0.979 . Whereas a possible positive correlation for the level $p<0.05$ does not exist, there is a significant negative correlation of -0.724 between the volume of the bread and the humidity.

\section{Conclusion}

The effect of adding bean flour significantly influences the decrease of rheology 
Table 4. Pearson's correlation between qualitative properties and nutrition values of the bread.

\begin{tabular}{lcccccc}
\hline & Moisture & Proteins & Fat & Carbohydrate & Cellulose & Minerals \\
\hline Bread weight & 0.563 & $0.947^{* *}$ & $0.859^{* *}$ & $-0.935^{* *}$ & $0.884^{* *}$ & $0.857^{* *}$ \\
Volume of bread & $-0.724^{*}$ & $-0.878^{* *}$ & $-0.956^{* *}$ & $0.942^{* *}$ & $-0.937^{* *}$ & $-0.870^{* *}$ \\
Specific volume of bread & -0.587 & $-0.849^{* *}$ & $-0.979^{* *}$ & $0.925^{* *}$ & $--0.964^{* *}$ & $-0.926^{* *}$ \\
\hline $\begin{array}{l}\text { * Correlation is significant at the } \\
\text { (2-tailed). }\end{array}$
\end{tabular}

properties of the dough, especially with regards to extensibility, resistance and dough energy; however it is more prominent with the mixtures M6 and M7. With the increase of the percentage of the bean flour at the produced breads, there is a gradual decrease of volume and specific volume of the bread which influences the organoleptic attributes of the bread. At the breads that are produced, we observe a significant increase in the content of protein, fat, cellulose and minerals as well as significant decrease of carbohydrates, which indicates the increase in nutrition values of the bean flour. The possible correlation between qualitative properties of bread with the nutrition values of the bread exists only in the level $p<0.01$ and it is higher for the volume of the bread and protein content, whereas for the level $p<0.05$ it does not exist.

\section{Conflicts of Interest}

The authors declare no conflicts of interest regarding the publication of this paper.

\section{References}

[1] Ronda, F., Abebe, W., Perez-Quirce, S. and Collar, C. (2015) Suitability of TEF Varieties in Mixed Wheat Flour Bread Matrices: A Physico-Chemical and Nutritional Approach. Journal of Cereal Science, 64, 139-146. https://doi.org/10.1016/j.jcs.2015.05.009

[2] Olaoye, O.A., Onilude, A.A. and Idowu, O.A. (2006) Quality Characteristics of Bread Produced from Composite Flours of Wheat, Plantain and Soybeans. African Journal of Biotechnology, 5, 1102-1106.

[3] Mepba, H.D., Eboh, L. and Nwaojigwa, S. (2007) Chemical, Functional and Baking Properties of Wheat-Plantain Composite Flours. African Journal of Food Agriculture Nutrition and Development, 7, 1-22.

[4] Olaoye, O.A. and Onilude, A.A. (2008) Microbiological, Proximate Analysis and Sensory Evaluation of Baked Products from Blends of Wheat-Breadfruit Flours. African Journal of Food Agriculture Nutrition and Development, 8, 192-208. https://doi.org/10.4314/ajfand.v8i2.19188

[5] Leahu, A. and Rosu, I.A. (2014) Effect of Soaking on the Cooking Quality and Color Parameters of Common Beans (Phaseolus vulgaris L.). Journal of Faculty of Food Engineering, 8, 244-251.

[6] Campos-Vegar, R., Oomah, B.D., Loarca-Pina, G. and Vergaracastaneda, H.A. (2013) Common Beans and Their Non-Digestible Fraction: Cancer Inhibitory Ac- 
tivity-An Overview. Foods, 2, 374-392. https://doi.org/10.3390/foods2030374

[7] Livingstone, A.S., Feng, J.J. and Malleshi, N.G. (1993) Development and Nutritional Quality Evaluation of Weaning Foods Based on Malted, Popped and Dried Wheat and Chickpea. International Journal of Food Science Technology, 28, 35-43. https://doi.org/10.1111/j.1365-2621.1993.tb01249.x

[8] Hughes, J.S. (1991) Potential Contribution of Dry Bean Dietary Fiber to Health. Food Technology, 45, 124-146.

[9] Madhujith, T., Naczk, M. and Shahidi, F. (2004) Antioxidant Activity of Common Beans (Phaseolus vulgaris L). Journal Food Lipids, 11, 220-233. https://doi.org/10.1111/j.1745-4522.2004.01134.x

[10] Xhabiri, G. and Sinani, A. (2011) Laboratory Analysis of Cereals, Flour, Dough and Baking Products (Analizat laboratorike të drithërave, miellrave, brumërave dhe produkteve të pjekjes). Çabej, Tetovo, 111-113.

[11] Kohajdová, Z., Karovičová, J. and Magala, M. (2013) Effect of Lentil and Bean Flours on Rheological and Baking Properties of Wheat Dough. Chemical Papers, 67, 398-407. https://doi.org/10.2478/s11696-012-0295-3

[12] Dhinda, F., Lakshmi, J.A., Prakash, J. and Dasappa, I. (2012) Effect of Ingredients on Rheological, Nutritional and Quality Characteristics of High Protein, High Fibre and Low Carbohydrate Bread. Food Bioprocess Technology, 5, 2998-3006. https://doi.org/10.1007/s11947-011-0752-y

[13] Anton, A.A., Ross, K.A., Lukow, O.M., Fulcher, R.G. and Arntfield, S.D. (2008) Influence of Added Bean Flour (Phaseolus vulgaris L.) on Some Physical and Nutritional Properties of Wheat Flour Tortillas. Food Chemistry, 109, 33-41. https://doi.org/10.1016/j.foodchem.2007.12.005

[14] Seleem, A.H. and Omran, A.A. (2014) Evaluation Quality of One Layer Flat Bread Supplemented with Beans and Sorghum Baked on Hot Metal Surface. Food and Nutrition Sciences, 5, 2246-2256. https://doi.org/10.4236/fns.2014.522238

[15] Manonmani, D., Bhol, S. and Bosco, S.J.H. (2014) Effect of Red Kidney Bean (Phaseolus vulgaris L.) Flour on Bread Quality. Open Access Library Journal, 1, 1-6. https://doi.org/10.4236/oalib.1100366

[16] Dodevska, M.S., Djordjevic, B.I., Sobajic, S.S., Miletic, I.D., Djordjevic, P.B. and Dimitrijevic-Sreckovic, V.S. (2013) Characterisation of Dietary Fibre Components in Cereals and Legumes Used in Serbian Diet. Food Chemistry, 141, 1624-1629. https://doi.org/10.1016/j.foodchem.2013.05.078 